\title{
Progress Report on the Assessment of the Material Performance for TCR Applications
}

Nuclear Science and Engineering Division 


\title{
About Argonne National Laboratory
}

Argonne is a U.S. Department of Energy laboratory managed by UChicago Argonne, LLC under contract DE-AC02-06CH11357. The Laboratory's main facility is outside Chicago, at 9700 South Cass Avenue, Argonne, Illinois 60439. For information about Argonne and its pioneering science and technology programs, see www.anl.gov.

\section{DOCUMENT AVAILABILITY}

Online Access: U.S. Department of Energy (DOE) reports produced after 1991 and a growing number of pre-1991 documents are available free at OSTI.GOV (http://www.osti.gov/), a service of the US Dept. of Energy's Office of Scientific and Technical Information.

\author{
Reports not in digital format may be purchased by the public from the \\ National Technical Information Service (NTIS): \\ U.S. Department of Commerce \\ National Technical Information Service \\ 5301 Shawnee Rd \\ Alexandria, VA 22312 \\ www.ntis.gov \\ Phone: (800) 553-NTIS (6847) or (703) 605-6000 \\ Fax: (703) 605-6900 \\ Email: orders@ntis.gov \\ Reports not in digital format are available to DOE and DOE contractors from the \\ Office of Scientific and Technical Information (OSTI): \\ U.S. Department of Energy \\ Office of Scientific and Technical Information \\ P.O. Box 62 \\ Oak Ridge, TN 37831-0062 \\ www.osti.gov \\ Phone: (865) 576-8401 \\ Fax: (865) 576-5728 \\ Email: reports@osti.gov
}

Disclaimer

This report was prepared as an account of work sponsored by an agency of the United States Government. Neither the United States Government nor any agency thereof, nor UChicago Argonne, LLC, nor any of their employees or officers, makes any warranty, express or implied, or assumes any legal liability or responsibility for the accuracy, completeness, or usefulness of any information, apparatus, product, or process disclosed, or represents that its use would not infringe privately owned rights. Reference herein to any specific commercial product, process, or service by trade name, trademark, manufacturer, or otherwise, does not necessarily constitute or imply its endorsement, recommendation, or favoring by the United States Government or any agency thereof. The views and opinions of document authors expressed herein do not necessarily state or reflect those of the United States Government or any agency thereof, Argonne National Laboratory, or UChicago Argonne, LLC. 


\section{Progress Report on the Assessment of the Material Performance for TCR Applications}

prepared by

Meimei Li, Xuan Zhang, Wei-Ying Chen, Florent Heidet

Nuclear Science and Engineering Division, Argonne National Laboratory

March 2020 


\title{
Progress Report on the Assessment of the Material Performance for TCR Applications
}

\author{
Meimei Li, Xuan Zhang, Wei-Ying Chen, Florent Heidet \\ Nuclear Science and Engineering Division \\ Argonne National Laboratory
}

\section{SUMMARY}

The objective of Argonne's materials research activities for the Transformational Challenge Reactor (TCR) program is to improve the understanding of material properties from additive manufacturing with the focus on understanding the creep and fatigue properties of additively manufactured materials. The material work conducted by Argonne provides support in developing and qualifying advanced materials and manufacturing processes to allow for innovative reactor design and licensing for the TCR. In FY 2020, Oak Ridge National Laboratory (ORNL) provided six ASTM standard sized creep specimens of additively-manufactured 316L stainless steel (AM 316L SS) for evaluation of the effect of post-build heat treatment on the creep property. Two different teat treatments were conducted on the as-built specimens, namely $1050^{\circ} \mathrm{C} / 1 \mathrm{~h}$ and $650^{\circ} \mathrm{C} / 1 \mathrm{~h}$ before creep testing. All specimens were creep tested at $550^{\circ} \mathrm{C}$ and 275 MPa to understand the effect of heat treatments. We have also received AM 316L SS printed in various forms including rods and sheets, wrought $316 \mathrm{~L}$ SS (as a reference material), and AM IN718 for tensile, creep and fatigue testing. Both ASTM standard sized specimens and subsized specimens are being fabricated or tested to contribute to a comprehensive mechanical property database of AM materials and to provide location-specific property data to the TCR digital platform. Mechanical testing at Argonne is conducted to ASME NQA-1 or its lab equivalent for quality assurance.

This report presents the results of the creep tests at $550^{\circ} \mathrm{C}$ and microstructural characterization for the assessment of the effect of the post-build heat treatment on the creep behavior of AM 316L SS. It also discusses ongoing efforts on obtaining location-dependent properties of AM 316L SS.

\section{PROGRESS AND STATUS}

\section{Introduction}

Type 316 austenitic stainless steel is one of the most widely used structural materials in all types of nuclear reactors including current nuclear power plants and next-generation advanced nuclear reactor concepts, e.g. sodium-cooled fast reactors, molten-salt reactors, and gas-cooled very high temperature reactors. Additive manufacturing as a disruptive manufacturing technology has opened up unprecedented opportunities for designing next-generation advanced 316 SS components with controlled microstructure and enabling smart designs of reactor structural components with complex geometries, design freedom and possibly enhanced properties. Previous studies have shown that AM 316 SS has significantly improved yield and tensile strength combined with good ductility over conventionally-made wrought 316 SS at low temperatures [13]. The high-temperature mechanical performance of AM $316 \mathrm{SS}$ is yet to be evaluated and fully understood. A comprehensive database of elevated temperature mechanical properties is needed 
for its core structural applications in the TCR, a gas-cooled microreactor being developed to demonstrate revolutionary technologies including additive manufacturing [4,5]. Argonne's work has been focused on the evaluation and understanding of the creep and fatigue performance of additively manufactured materials.

\section{Creep Property of AM 316L SS}

\section{Experimental}

In FY 2019, we conducted six creep tests at $650^{\circ} \mathrm{C}$ using ASTM-standard round bar specimens (Fig. 1) of AM 316L SS provided by ORNL [6]. The specimens were fabricated from Build 20190308 printed by a laser powder bed fusion process using a Concept Laser-M2 printer [6]. Three of them were fabricated from rods printed in laser 1 mode (specimen IDs, L101, L102, L103), and the other three from rods printed in laser 2 mode (specimen ID, L201, L202, L203). This two-laser system enables direct one-to-one batch variability within a single build while keeping all other variables constant. The three specimens of laser 1 mode were creep tested at $650^{\circ} \mathrm{C}$ at 175,200 , and $225 \mathrm{MPa}$, respectively, and the three specimens of laser 2 mode were tested at the same temperature and stress conditions to evaluate the batch variability.

Six additional ASTM-standard round bar specimens were provided by ORNL in November 2019 (FY 2020) for the evaluation of the influence of post-build heat treatment on the creep property of AM 316L SS. These specimens were also fabricated from Build 20190308 rods with three of them in laser 1 mode (specimen IDs, L104, L105, L106), and the other three in laser 2 mode (specimen ID, L204, L205, L206). Post-build heat treatments were conducted at Argonne at $1050^{\circ} \mathrm{C}$ for one hour followed by rapid cooling on specimens $\mathrm{L} 105$ and $\mathrm{L} 205$, and at $650^{\circ} \mathrm{C}$ for one hour followed by furnace cooling on specimens L106 and L206, respectively. Each specimen was individually encapsulated in a quart tube under vacuum, and heat treated in an air furnace. Specimens L104 and L204 were in the as-built condition before creep tests. All specimens were creep tested under the same condition, namely, $550^{\circ} \mathrm{C}$ and $275 \mathrm{MPa}$. Table 1 provides a list of ASTM-standard creep specimens and testing conditions of AM 316L SS.

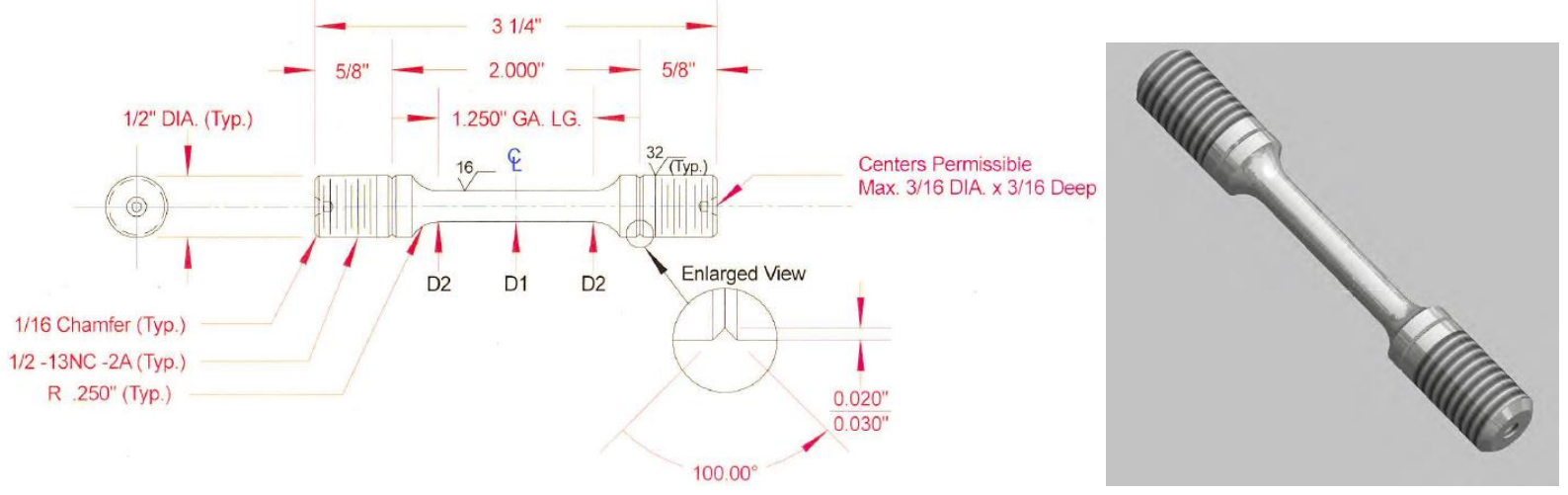

Figure 1. Schematic of ASTM-standard round bar creep specimens (unit: in). 
Creep tests were conducted according to ASTM Standard E139-11, "Standard Test Methods for Conducting Creep, Creep-Rupture, and Stress-Rupture Tests on Metallic Materials." Tests were carried out on ATS Series 2300 Lever Arm Creep Testing Systems integrated with WinCCS II computer control and data acquisition software package (Fig. 2). Each creep frame is equipped with a three-zone split-tube furnace capable of operation up to $1100^{\circ} \mathrm{C}$. An averaging extensometer frame was mounted on the specimen to measure the specimen displacement.

Table 1. List of ASTM-standard round bar creep specimens and test conditions of AM 316 L SS.

\begin{tabular}{|c|l|l|l|c|c|c|c|}
\hline $\begin{array}{c}\text { Specimen } \\
\text { ID }\end{array}$ & Build ID & $\begin{array}{c}\text { Laser } \\
\text { mode }\end{array}$ & $\begin{array}{c}\text { Specimen } \\
\text { Type }\end{array}$ & Condition & $\begin{array}{c}\text { Test } \\
\mathrm{T} \\
\left({ }^{\circ} \mathrm{C}\right)\end{array}$ & $\begin{array}{c}\text { Stress } \\
(\mathrm{MPa})\end{array}$ & Environ. \\
\hline L101 & 20190308 & Laser 1 & ASTM & As-built & 650 & 225 & Air \\
\hline L102 & 20190308 & Laser 1 & ASTM & As-built & 650 & 200 & Air \\
\hline L103 & 20190308 & Laser 1 & ASTM & As-built & 650 & 175 & Air \\
\hline L104 & 20190308 & Laser 1 & ASTM & As-built & 550 & 275 & Air \\
\hline L105 & 20190308 & Laser 1 & ASTM & $1050^{\circ} \mathrm{C} / 1 \mathrm{~h}$ & 550 & $*$ & Air \\
\hline L106 & 20190308 & Laser 1 & ASTM & $650^{\circ} \mathrm{C} / 1 \mathrm{~h}$ & 550 & 275 & Air \\
\hline L201 & 20190308 & Laser 2 & ASTM & As-built & 650 & 225 & Air \\
\hline L202 & 20190308 & Laser 2 & ASTM & As-built & 650 & 200 & Air \\
\hline L203 & 20190308 & Laser 2 & ASTM & As-built & 650 & 175 & Air \\
\hline L204 & 20190308 & Laser 2 & ASTM & As-built & 550 & 275 & Air \\
\hline L205 & 20190308 & Laser 2 & ASTM & $1050^{\circ} \mathrm{C} / 1 \mathrm{~h}$ & 550 & 275 & Air \\
\hline L206 & 20190308 & Laser 2 & ASTM & $650^{\circ} \mathrm{C} / 1 \mathrm{~h}$ & 550 & 275 & Air \\
\hline
\end{tabular}

*L105 failed at $550^{\circ} \mathrm{C}$ during initial loading to $375 \mathrm{MPa}$. The applied creep stress was then reduced to $275 \mathrm{MPa}$ for other five specimens.

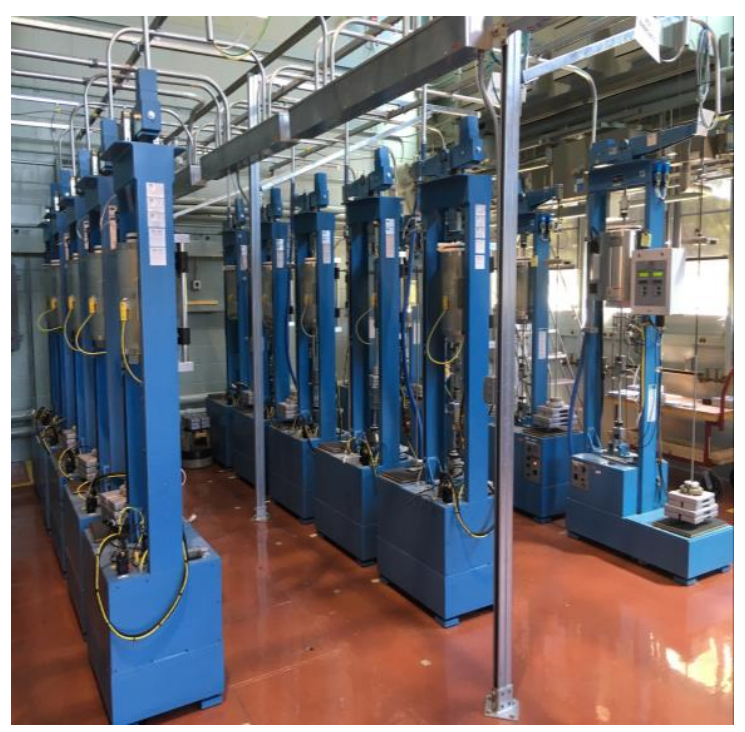

Figure 2. Argonne's creep test systems. 


\section{Results}

The $650^{\circ} \mathrm{C}$ creep data of AM 316L SS was presented in a previous report [6]. In summary, specimens in laser 1 and laser 2 modes showed comparable creep behavior. AM 316L SS showed a very short steady-state creep, compared with conventional Type 316 SS. The minimum creep rate was reached in the first few hours followed by a continuous increase in creep rate to the final failure. The minimum creep rate of AM 316L SS followed a power law relationship with the applied stress, $\dot{\varepsilon}=A \sigma^{n}$, with the power exponent of $\mathrm{n}=12$, which implies a low-temperature dislocation creep mechanism.

Figure 3 shows the creep strain as a function of time for the five creep specimens tested at $550^{\circ} \mathrm{C}$ and $275 \mathrm{MPa}$ to evaluate the influence of the post-build heat treatment on creep properties. L105 failed at $550^{\circ} \mathrm{C}$ during initial loading to $375 \mathrm{MPa}$. The applied stress was reduced for other five specimens, and they were tested at $550^{\circ} \mathrm{C}$ and $275 \mathrm{MPa}$. The creep rupture data are given in Fig. 4. Post-build heat treatment of $1050^{\circ} \mathrm{C} / 1 \mathrm{~h}$ significantly reduced the creep life, while the heat treatment of $650^{\circ} \mathrm{C} / 1 \mathrm{~h}$ slightly increased the creep life compared with the creep life of the as-built specimen. Specimens of laser 1 mode (L104 and L106) showed somewhat longer creep lives than specimens of laser 2 mode (L204 and L206). The as-built specimens and the $650^{\circ} \mathrm{C} / 1 \mathrm{~h}$ heat treated specimens had a very short steady-state stage (a few percent of the total life) followed by an accelerated creep until the final failure, similar to the observations of the $650^{\circ} \mathrm{C}$ creep tests. The $1050^{\circ} \mathrm{C} / 1 \mathrm{~h}$ heat treated specimen had a much more pronounced steady-state creep, resembling the creep behavior of conventional $316 \mathrm{SSs}$. The minimum creep rate of the $1050^{\circ} \mathrm{C} / 1 \mathrm{~h}$ heat treated specimen is about six times higher than the minimum creep rates of all other specimens, as shown in Fig. 5. The minimum creep rates of the $650^{\circ} \mathrm{C} / 1 \mathrm{~h}$ heat treated specimens are smaller than those of the as-built specimens. Specimens of laser 1 mode have somewhat lower creep rates than specimens of laser 2 mode. Figure 6 shows that all the specimens exhibited slant fracture.

The creep property data of AM 316L SS at 550 and $650^{\circ} \mathrm{C}$ are summarized in Table 2 . Figure 7 shows the creep rupture data of AM 316L SS at 550 and $650^{\circ} \mathrm{C}$ and compares the $550^{\circ} \mathrm{C}$ data with the creep rupture equation at $550^{\circ} \mathrm{C}$ for conventional $316 \mathrm{SS}$ developed by ORNL [7]. It is shown that AM 316L SS has a shorter creep life than Type 316 SS regardless of the AM specimen condition. Post-build heat treatment of $650^{\circ} \mathrm{C} / 1 \mathrm{~h}$ improved the creep rupture life of AM $316 \mathrm{~L}$, which is still below that for conventional 316 SS. Post-build solution annealing treatment of $1050^{\circ} \mathrm{C} / 1 \mathrm{~h}$ significantly shorten the creep life. Figure 8 summarizes the minimum creep rate data for AM $316 \mathrm{~L} \mathrm{SS}$ at 550 and $650^{\circ} \mathrm{C}$. Creep data obtained up to date show that the batch variability between laser 1 and laser 2 modes is insignificant. 


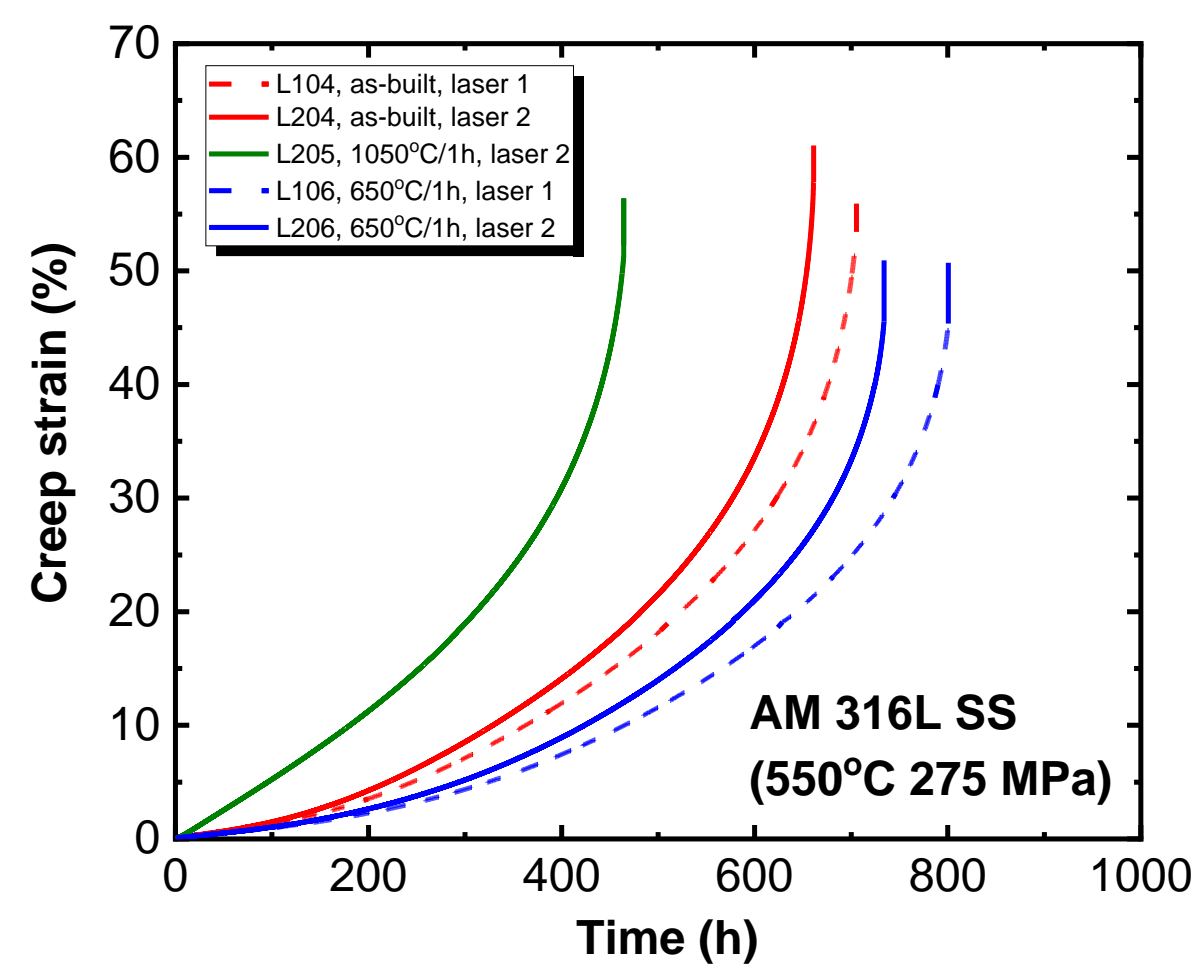

Figure 3. Creep strain as a function of time for AM $316 \mathrm{~L} \mathrm{SS}$ tested at $550^{\circ} \mathrm{C}$ and $275 \mathrm{MPa}$.

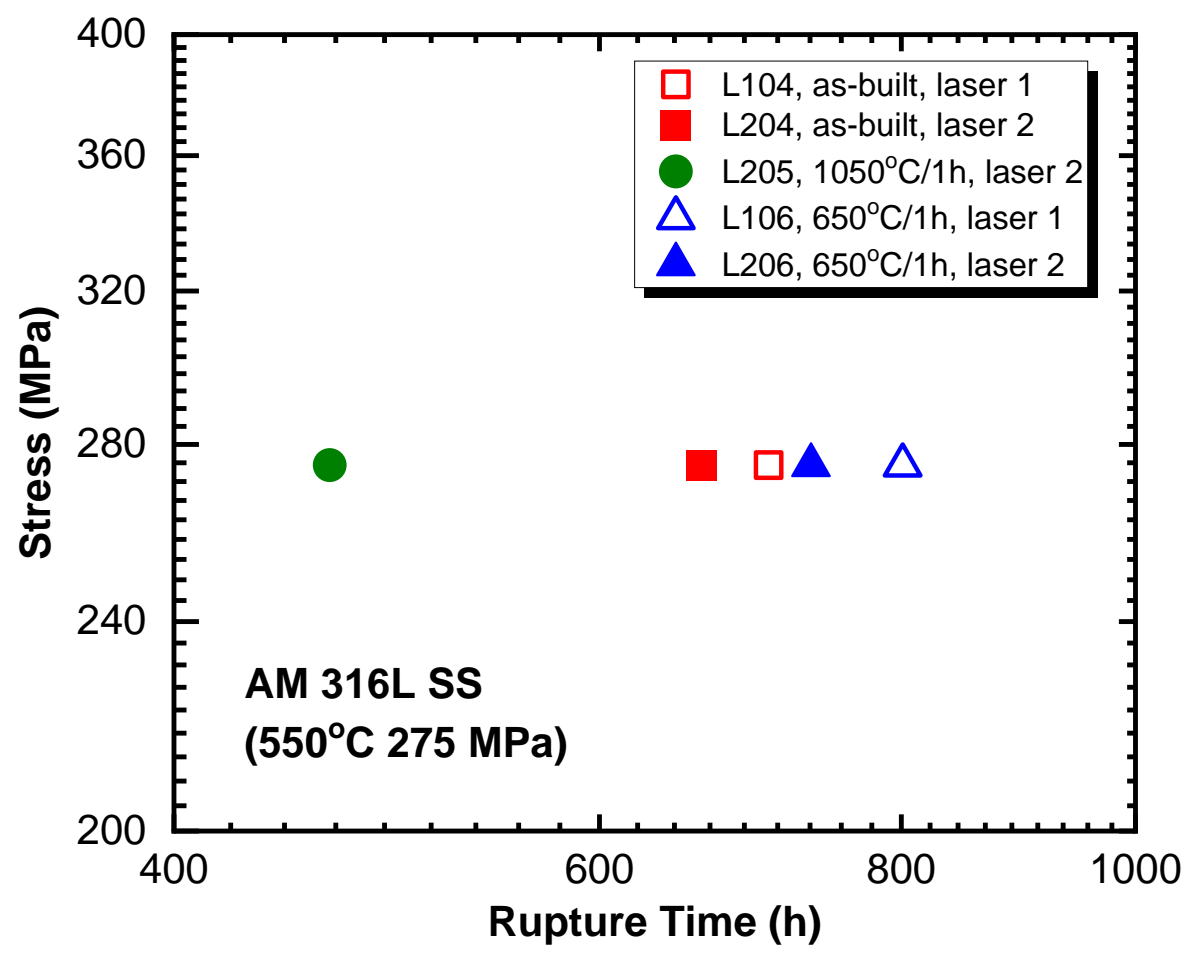

Figure 4. Creep rupture data for AM 316L SS tested at $550^{\circ} \mathrm{C}$ and $275 \mathrm{MPa}$. 


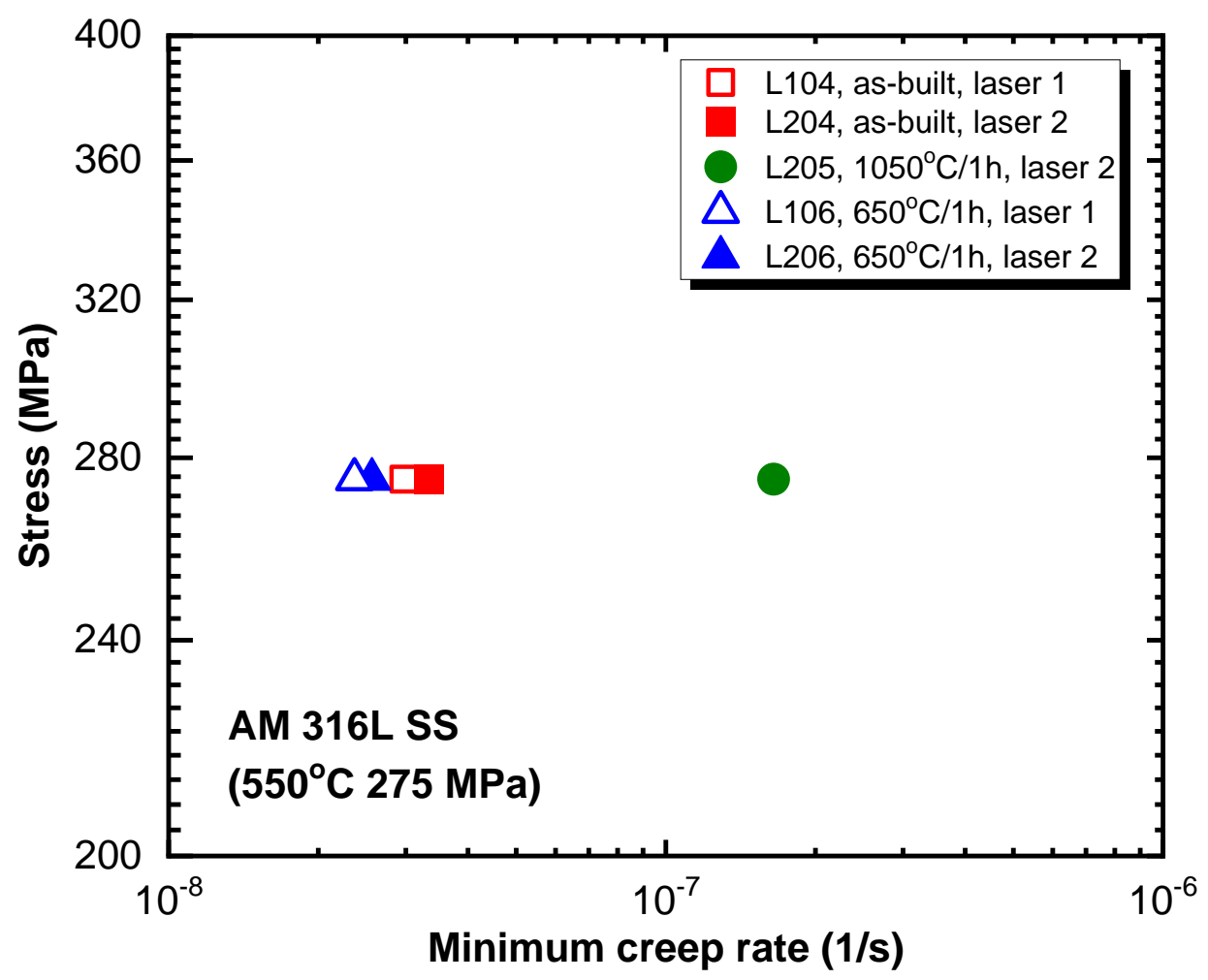

Figure 5. Minimum creep strain rates for AM $316 \mathrm{~L}$ SS tested at $550^{\circ} \mathrm{C}$ and $275 \mathrm{MPa}$.

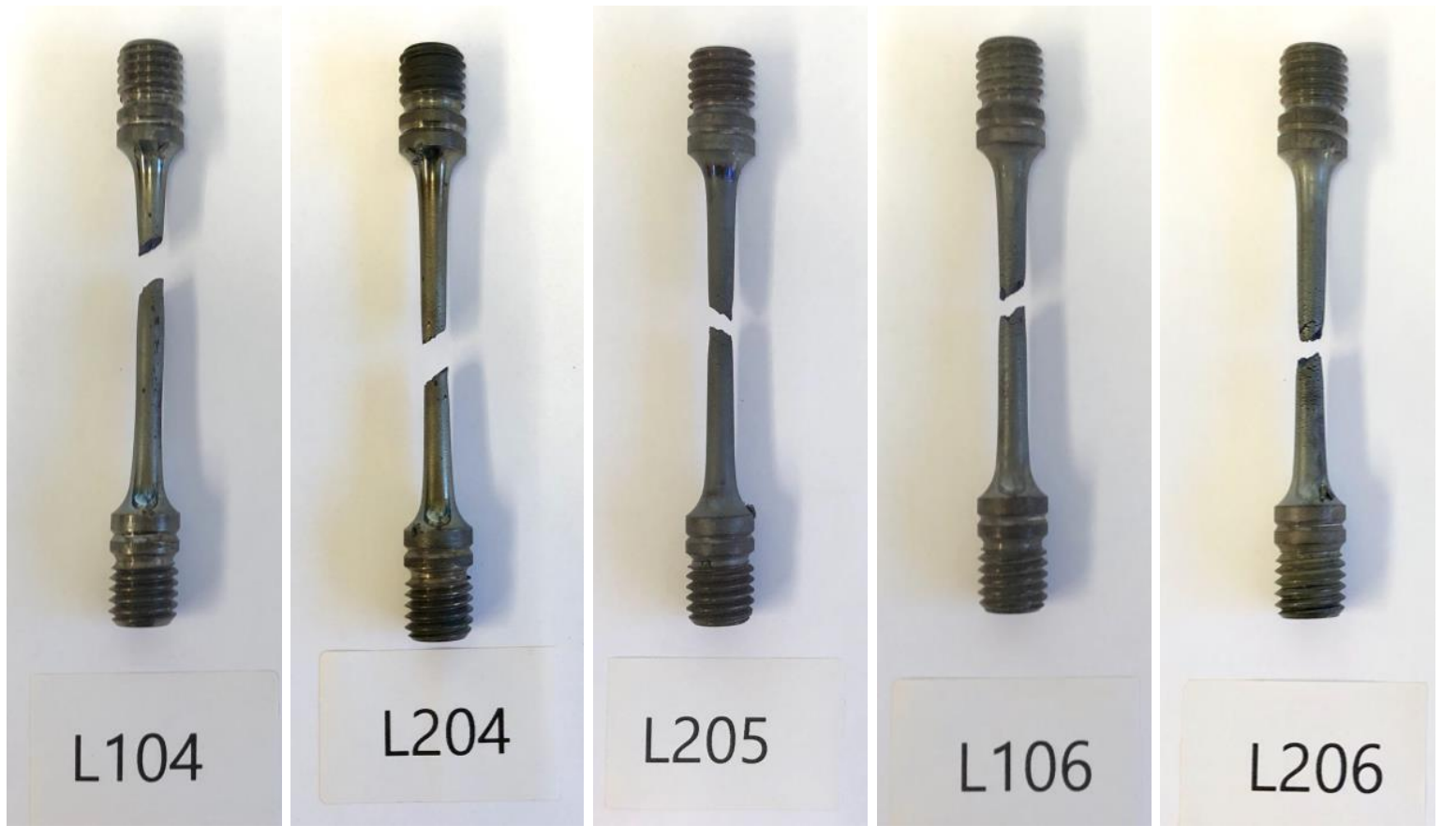

Figure 6. Photographs of the AM 316L SS creep-ruptured specimens. 
Table 2. Creep property data of AM $316 \mathrm{~L} \mathrm{SS}$ tested at 550 and $650^{\circ} \mathrm{C}$.

\begin{tabular}{|c|l|l|l|l|l|l|l|l|}
\hline $\begin{array}{c}\text { Specimen } \\
\text { ID }\end{array}$ & $\begin{array}{l}\text { Laser } \\
\text { mode }\end{array}$ & Condition & $\begin{array}{c}\text { Test } \\
\text { Temp } \\
\left({ }^{\circ} \mathrm{C}\right)\end{array}$ & $\begin{array}{c}\text { Stress } \\
(\mathrm{MPa})\end{array}$ & $\begin{array}{l}\text { Rupture } \\
\text { time (h) }\end{array}$ & $\begin{array}{c}\text { Minimum } \\
\text { Creep } \\
\text { rate }(1 / \mathrm{s})\end{array}$ & $\begin{array}{c}\text { Creep } \\
\text { rupture } \\
\text { strain } \\
(\%)\end{array}$ & $\begin{array}{l}\text { R.A. } \\
(\%)\end{array}$ \\
\hline L101 & Laser 1 & As-built & 650 & 225 & 13.8 & $1.22 \times 10^{-6}$ & 46.9 & 45.1 \\
\hline L102 & Laser 1 & As-built & 650 & 200 & 41.6 & $2.59 \times 10^{-7}$ & 40.7 & 43.0 \\
\hline L103 & Laser 1 & As-built & 650 & 175 & 150.3 & $6.41 \times 10^{-8}$ & 45.8 & 44.2 \\
\hline L104 & Laser 1 & As-built & 550 & 275 & 705.4 & $2.97 \times 10^{-8}$ & 55.9 & 53.5 \\
\hline L106 & Laser 1 & $650^{\circ}$ C/1h & 550 & 275 & 800.6 & $2.36 \times 10^{-8}$ & 50.7 & 53.4 \\
\hline L201 & Laser 2 & As-built & 650 & 225 & 13.0 & $1.39 \times 10^{-6}$ & 47.5 & 46.0 \\
\hline L202 & Laser 2 & As-built & 650 & 200 & 43.9 & $2.53 \times 10^{-7}$ & 53.5 & 46.9 \\
\hline L203 & Laser 2 & As-built & 650 & 175 & 144.5 & $6.61 \times 10^{-8}$ & 43.2 & 44.2 \\
\hline L204 & Laser 2 & As-built & 550 & 275 & 661.0 & $3.33 \times 10^{-8}$ & 61.0 & 58.1 \\
\hline L205 & Laser 2 & $1050^{\circ} \mathrm{C} / 1 \mathrm{~h}$ & 550 & 275 & 464.4 & $1.65 \times 10^{-7}$ & 56.4 & 54.7 \\
\hline L206 & Laser 2 & $650^{\circ} \mathrm{C} / 1 \mathrm{~h}$ & 550 & 275 & 734.0 & $2.56 \times 10^{-8}$ & 50.9 & 57.7 \\
\hline
\end{tabular}

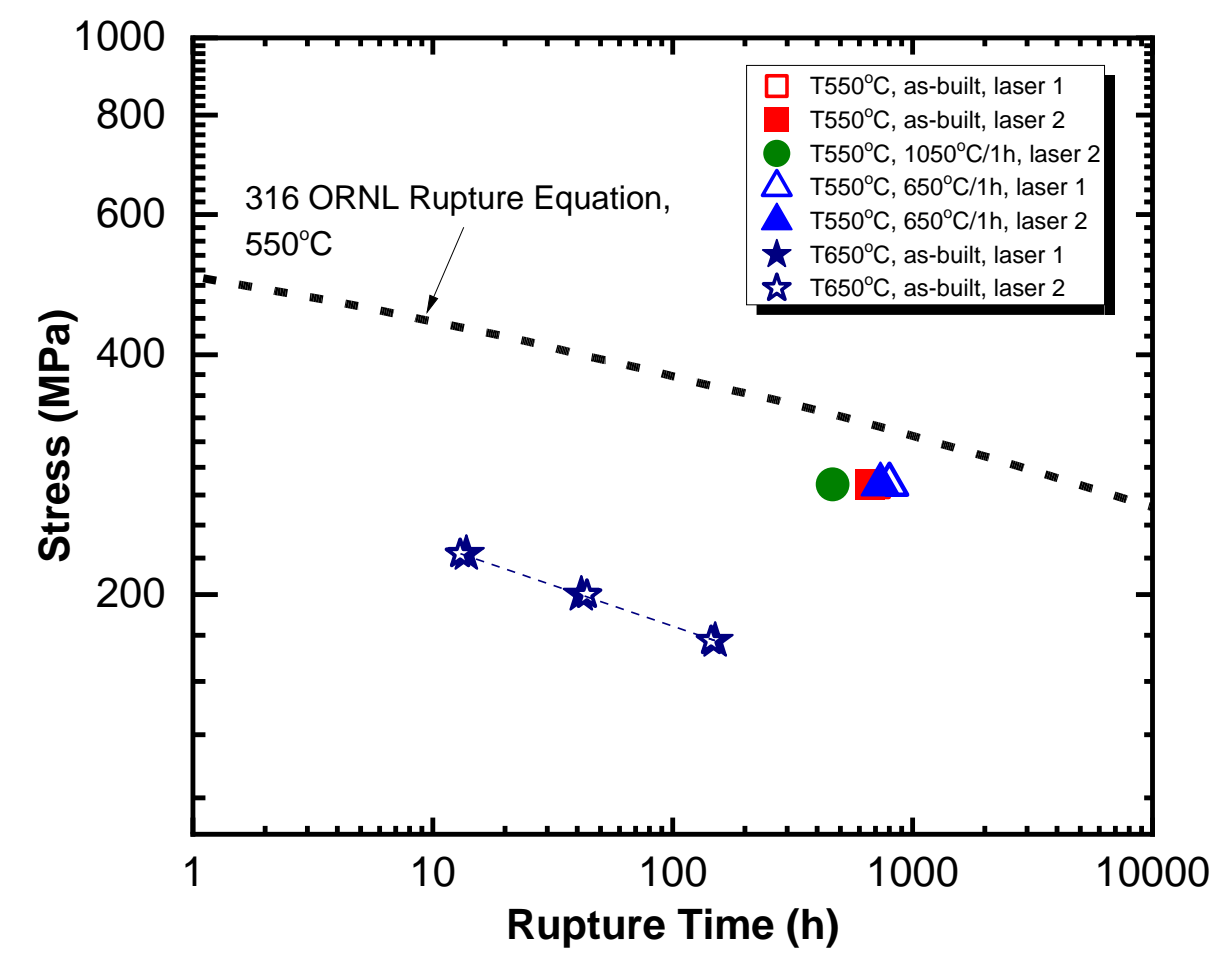

Figure 7. Creep rupture data for AM 316L SS tested at 550 and $650^{\circ} \mathrm{C}$ and comparison with the 316 ORNL rupture equation $\left(550^{\circ} \mathrm{C}\right)$ [7]. 


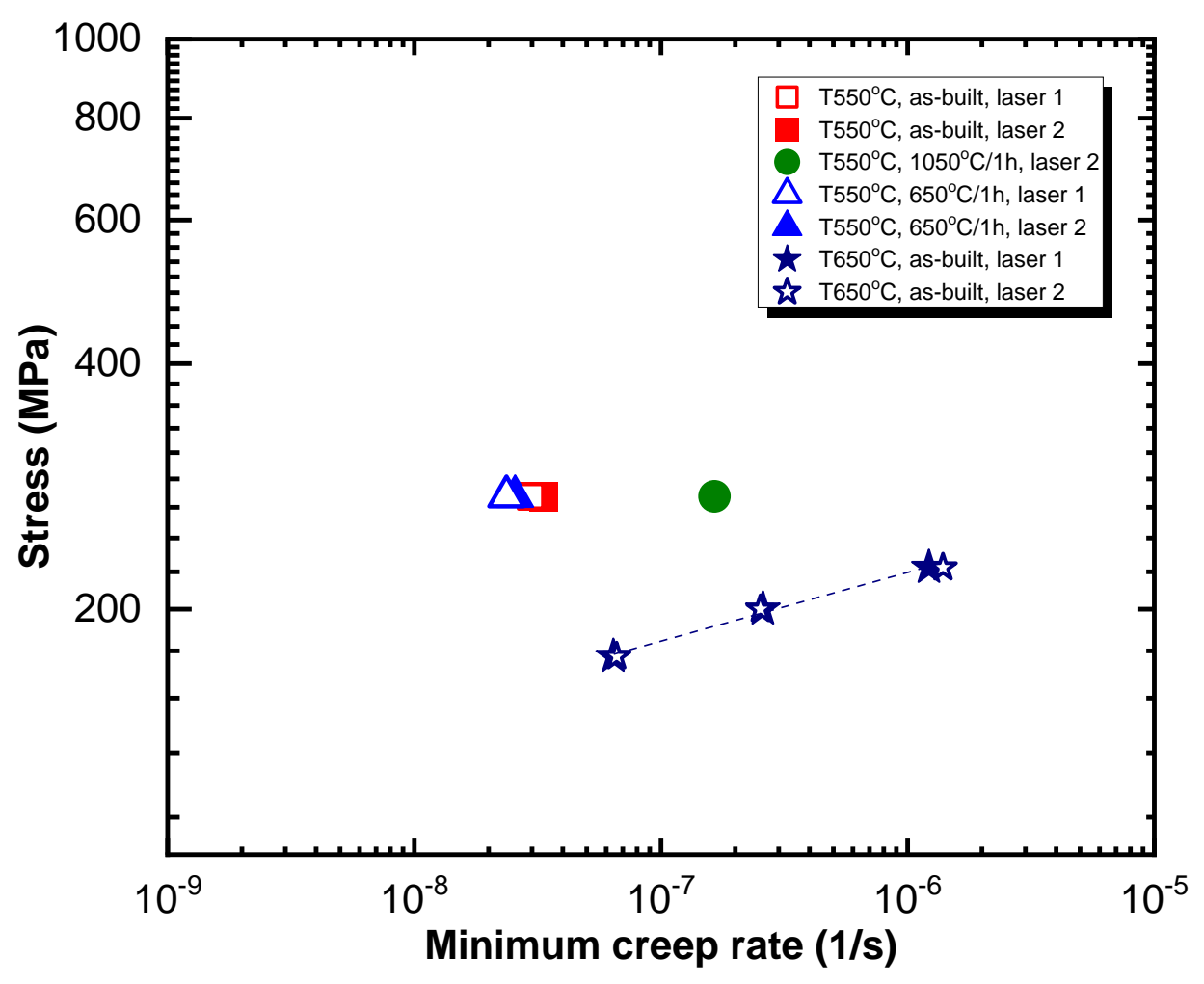

Figure 8. Minimum creep strain rates for AM $316 \mathrm{~L}$ SS tested at 550 and $650^{\circ} \mathrm{C}$.

\section{Microstructure of AM 316L SS}

To examine the microstructure of the as-built AM $316 \mathrm{~L} \mathrm{SS}$, a thin sheet $(\sim 0.25 \mathrm{~mm}$ thick) was sectioned from a rod (laser 1 mode, 20190308 build) approximately 0.7 " away from an end of the rod. Disk specimens of $3 \mathrm{~mm}$ in diameter were made from the thin sheet for transmission electron microscopy (TEM). TEM disk specimens were electropolished to perforation using an electrolyte of 5\% methanol and $95 \%$ perchloric acid at $\sim-40^{\circ} \mathrm{C}$.

TEM images at various magnifications in Fig. 9 reveal well-organized dislocation cells in the as-built AM 316L SS. The cell size is $\sim 500 \mathrm{~nm}$. The dislocation density is very low inside cells. Both cell boundaries and grain boundaries are decorated with precipitate particles. EDS elemental mapping shows that the particles are oxides enriched in $\mathrm{Si}, \mathrm{Mn}$; elemental segregation was observed at cell boundaries which are enriched in $\mathrm{Cr}$ and $\mathrm{Mo}$ and depleted of $\mathrm{Fe}$, as shown in Fig. 10. The observations are consistent with the findings reported in the literature, e.g. [8]. 

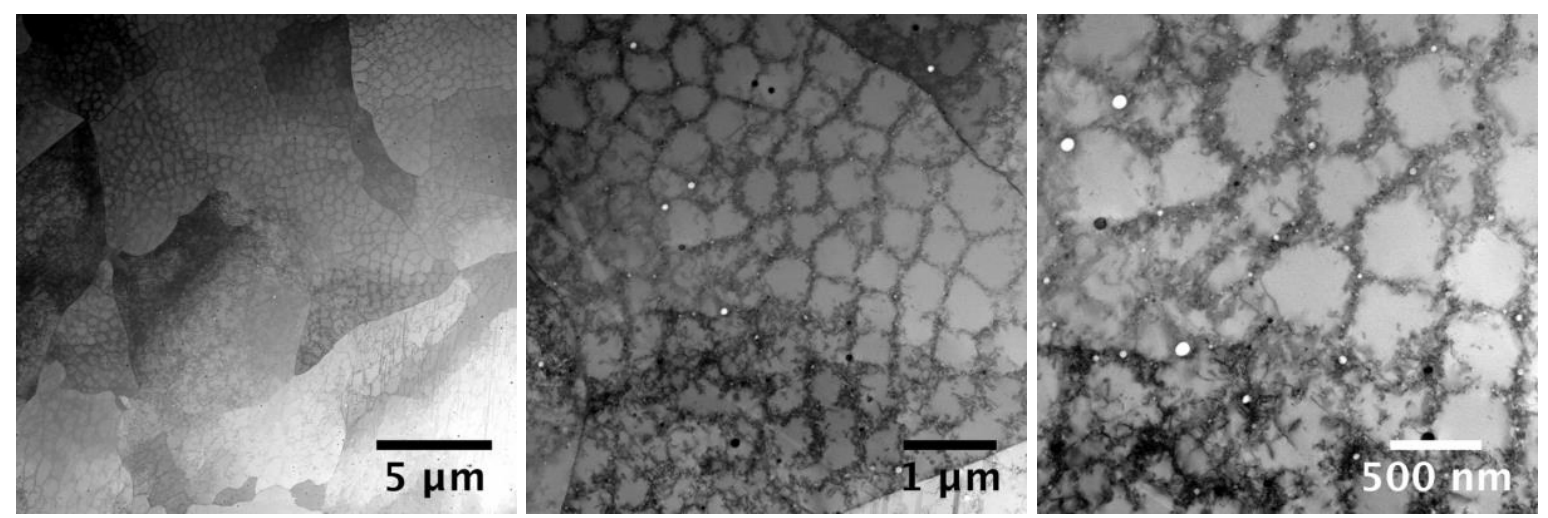

Figure 9. TEM micrographs showing the microstructure of the as-built AM 316 L SS (Laser 1 Build 20190308).
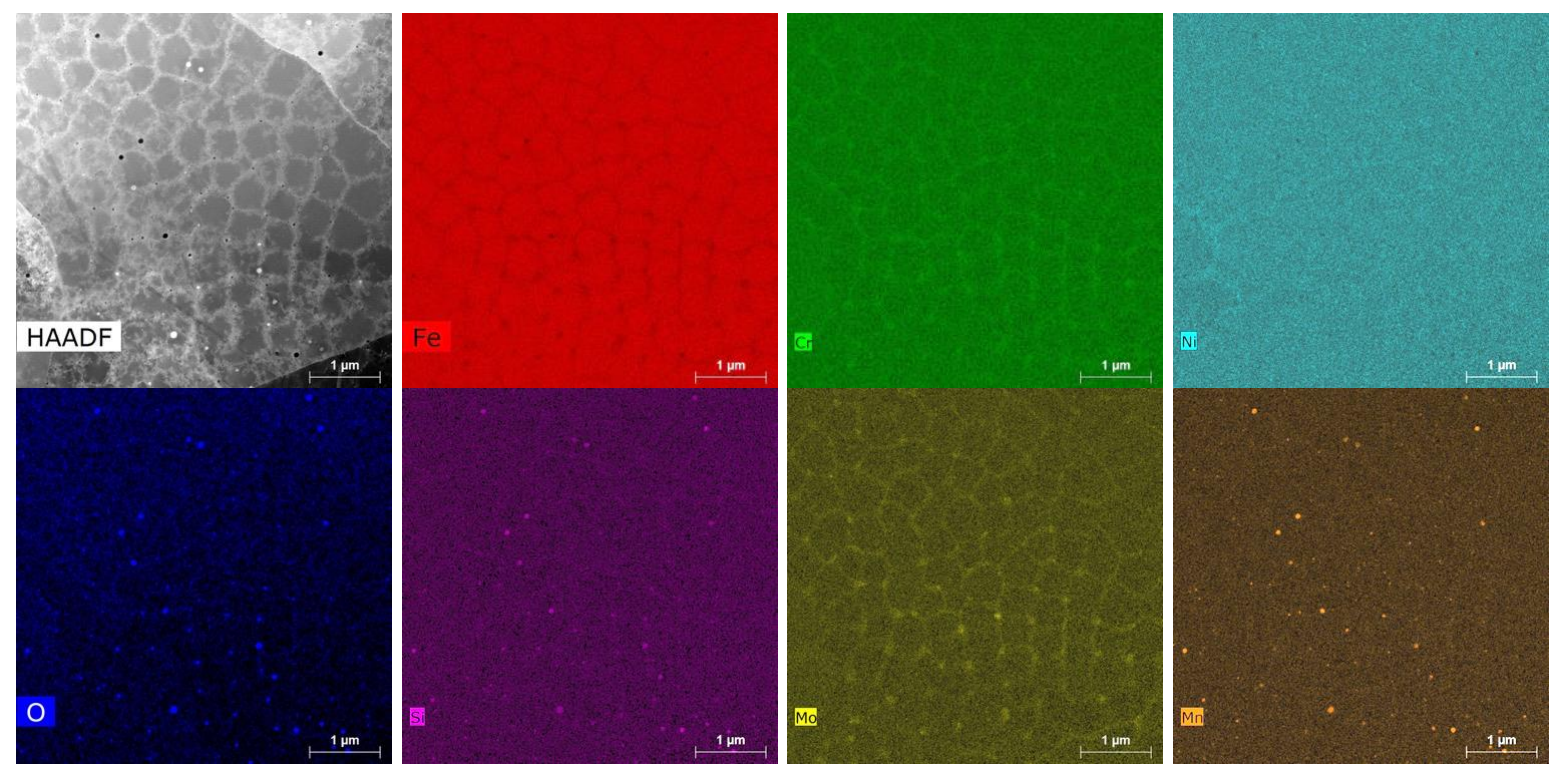

Figure 10. HAADF micrograph and EDS elemental maps of the as-built AM 316 L SS.

Heat treatment at $1050^{\circ} \mathrm{C} / 1 \mathrm{~h}$ effectively removed the dislocation cell structure and elemental segregation at cell boundaries observed in the as-built condition, as shown in Figs. 11 and 12. Note that TEM disk specimens were taken from the grip section of specimen L205 who experienced an additional thermal exposure of $550^{\circ} \mathrm{C}$ for $464 \mathrm{~h}$ during the creep test. This thermal exposure is expected to have an insignificant effect on TEM-visible microstructure. Unlike conventional solution-annealed Type $316 \mathrm{SS}$, dislocation lines and precipitates were observed within equiaxed grains after the heat treatment of $1050^{\circ} \mathrm{C} / 1 \mathrm{~h}$ in $\mathrm{AM} 316 \mathrm{~L}$ SS. EDS elemental mapping (Fig. 12) shows oxide particles enriched in $\mathrm{Cr}$ and $\mathrm{Mn}$, which have different chemistry from those observed in the as-built condition (Fig. 10). The particle size in the $1050^{\circ} \mathrm{C} / 1 \mathrm{~h}$ heat treated specimen is significantly larger, with the mean size of $87 \mathrm{~nm}$ relative to the particle mean size of $25 \mathrm{~nm}$ in the as-built specimen (Fig. 13). It is also noted that particles in the as-built specimen appear to have a bimodal size distribution. 

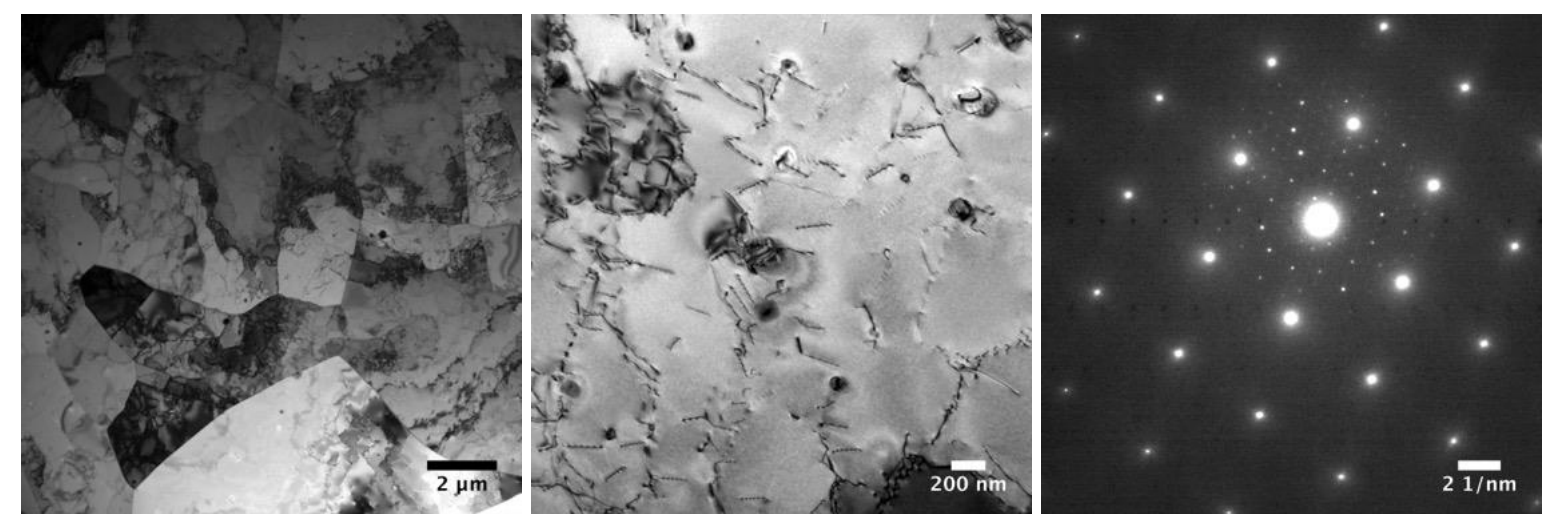

Figure 11. TEM micrographs showing the microstructure of the AM $316 \mathrm{~L}$ SS heat treated at $1050^{\circ} \mathrm{C} / 1 \mathrm{~h}$. The TEM specimen was taken from the grip section of specimen L205.
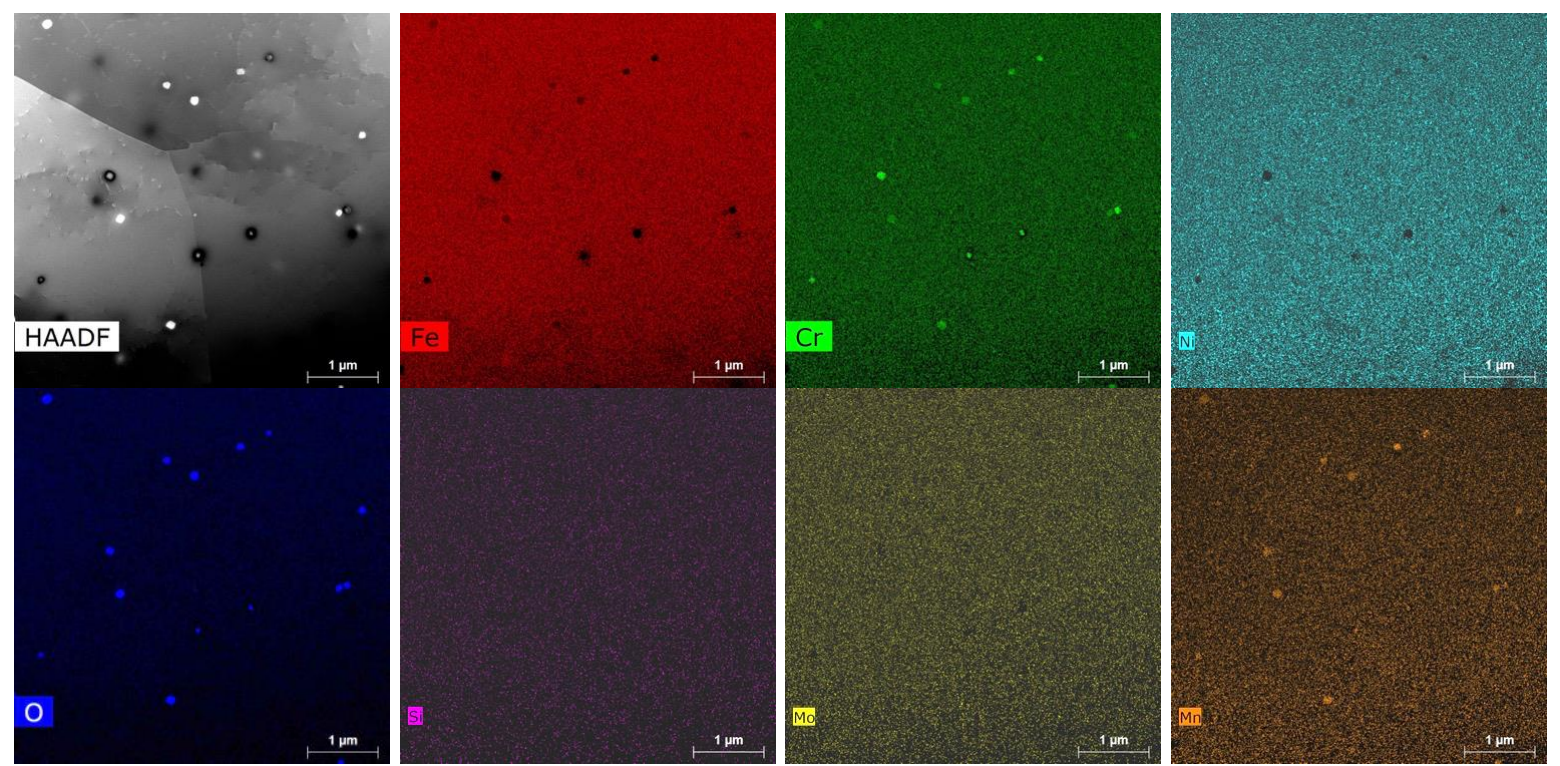

Figure 12. HAADF micrograph and EDS elemental maps of the AM $316 \mathrm{~L}$ SS heat treated at $1050^{\circ} \mathrm{C} / 1 \mathrm{~h}$. The TEM specimen was taken from the grip section of specimen L205.
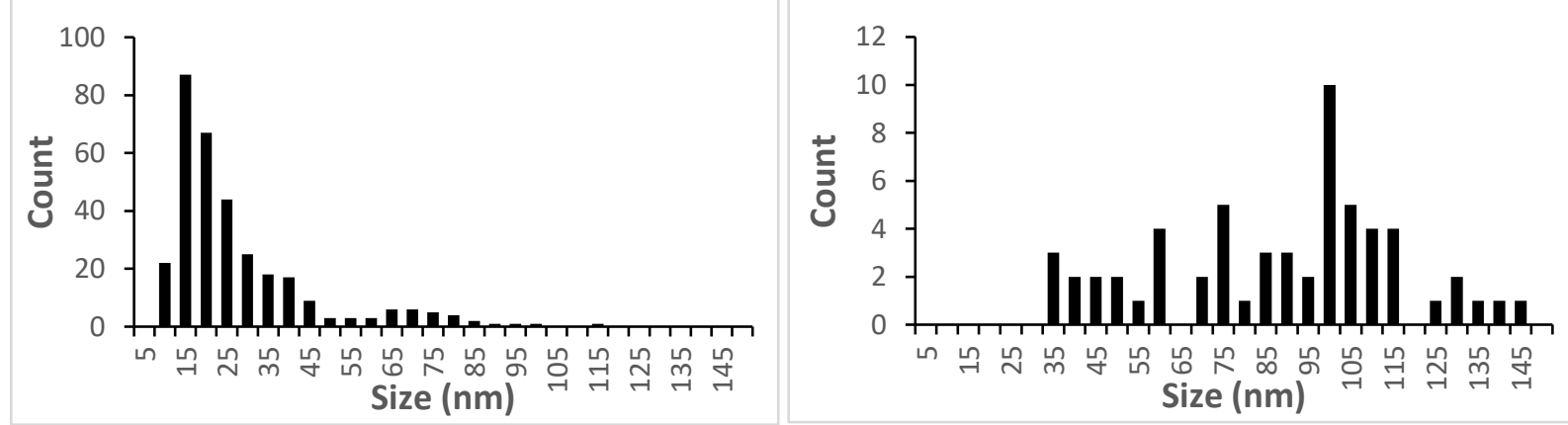

Figure 13. Particle size distributions in the as-built condition (mean size $=25 \mathrm{~nm}$ ) (left) and in the $1050^{\circ} \mathrm{C} / 1 \mathrm{~h}$ heat treated condition (mean size $=87 \mathrm{~nm}$ ) (right). 
TEM disk specimens were cut from the gauge section of specimens after creep tests to examine the microstructural change during creep deformation. Electropolishing of TEM disks was a challenge due to the presence of cracks, voids, or porosity. Electropolished thin foil specimens were further ion milled to obtain appreciable thin areas for TEM observations.

Figure 14 shows the microstructure of the as-built AM 316L SS after the creep test at $550^{\circ} \mathrm{C} / 275 \mathrm{MPa}$. Specimen was taken from the gauge of specimen L204. It was found that the initial dislocation cells mostly evolved into dislocation tangles with some cell structures still observable but less well defined. A similar observation was made in the $650^{\circ} \mathrm{C} / 1 \mathrm{~h}$ heat treated specimen after the creep test, i.e. heavy dislocation tangles, but the cell structure was not evident, as shown in Fig. 15 (TEM specimen was taken from the gauge section of specimen L206). The through-focus imaging reveal features with lower electron density features in some of the grains, segregated along dislocation lines. These features are possibly voids or precipitates, and their exact nature is to be resolved. High density of dislocations was also observed in the $1050^{\circ} \mathrm{C} / 1 \mathrm{~h}$ heat treated specimen after the creep test, as shown in Fig. 16. It appears that the end microstructure after the creep test was similar regardless of the initial state.

Fast cooling rates during the laser powder bed fusion process can produce highly nonequilibrium microstructure and high residual stress. Post-build heat treatment of $650^{\circ} \mathrm{C} / 1 \mathrm{~h}$ can potentially reduce the residual stress in the as-built condition. The solution annealing treatment at $1050^{\circ} \mathrm{C} / 1 \mathrm{~h}$ removed the dislocation cell structure and elemental segregation at boundaries, resulting in equilibrium structure and homogeneous solute distribution. The oxide particles in the as-built condition, $(\mathrm{Mn}, \mathrm{Si}) \mathrm{O}$ were replaced with oxides, $(\mathrm{Mn}, \mathrm{Cr}) \mathrm{O}$, potentially more stable in equilibrium, and $\mathrm{Si}$ atoms dissolved in the solution. It is suggested that the dislocation cell structure in the as-built condition is largely responsible for the observed low minimum creep rate. This structure is however unstable, and can readily undergo dynamic recovery during creep, resulting in an accelerated creep. The oxide particles distributed along the cell boundaries may also play a role in reducing the creep rate and slow the recrystallization process during the post-build solution annealing treatment.
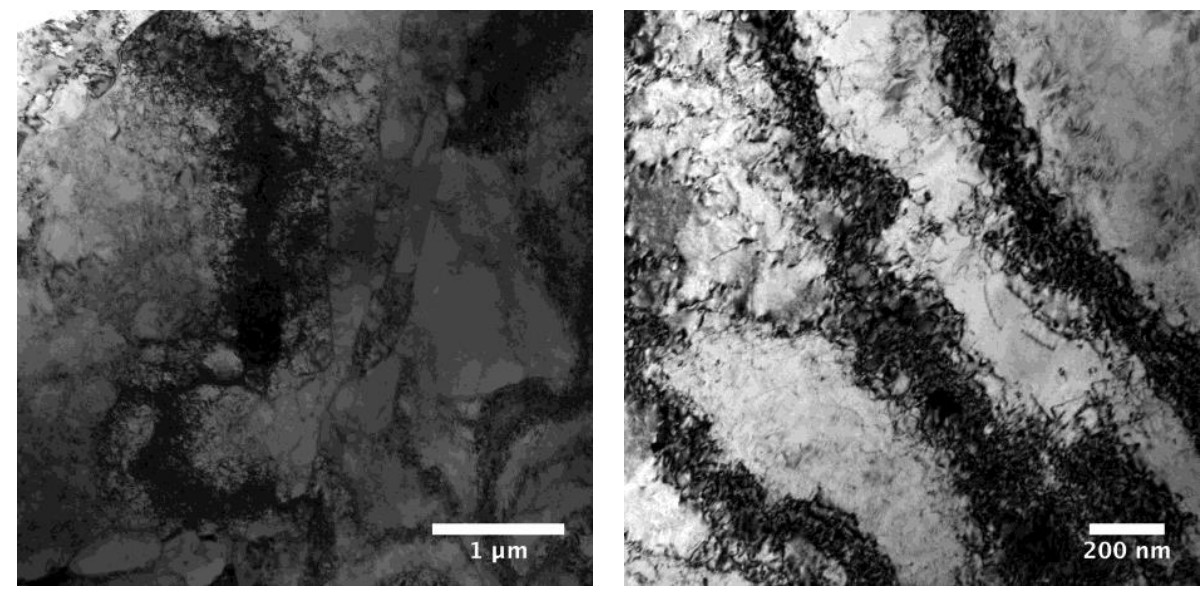

Figure 14. TEM micrographs showing the microstructure of the as-built AM 316 L SS after creep test at $550^{\circ} \mathrm{C} / 275 \mathrm{MPa}$. TEM specimen was taken from the gauge section of specimen L204. 


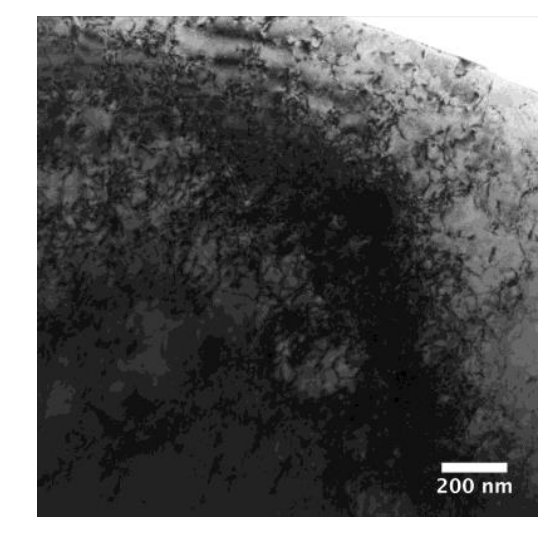

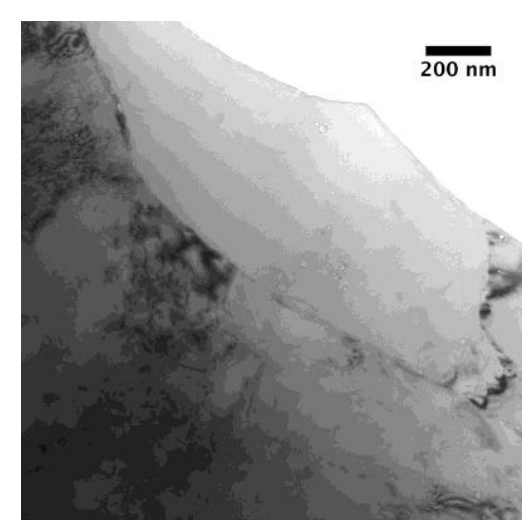

Under-focus

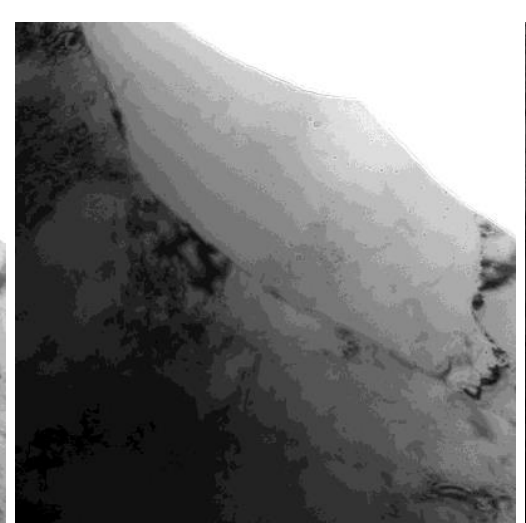

Over-focus

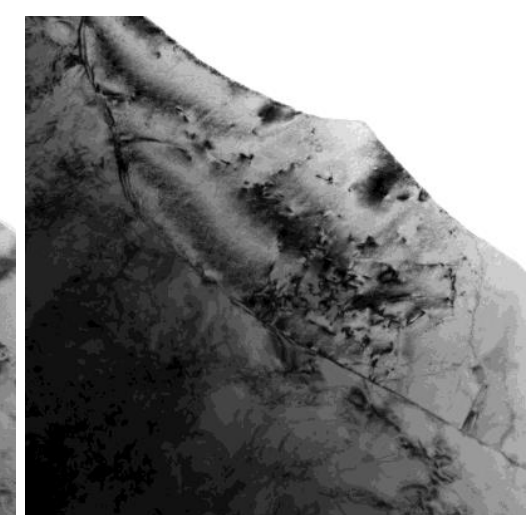

In-focus

Figure 15 . TEM micrographs showing the microstructure of the $650^{\circ} \mathrm{C} / 1 \mathrm{~h}$ heat treated $\mathrm{AM} 316 \mathrm{~L}$ $\mathrm{SS}$ after creep test at $550^{\circ} \mathrm{C} / 275 \mathrm{MPa}$. The under-focus, over-focus, and in-focus images show voids or precipitates inside a grain. TEM specimen was taken from the gauge section of specimen L206.
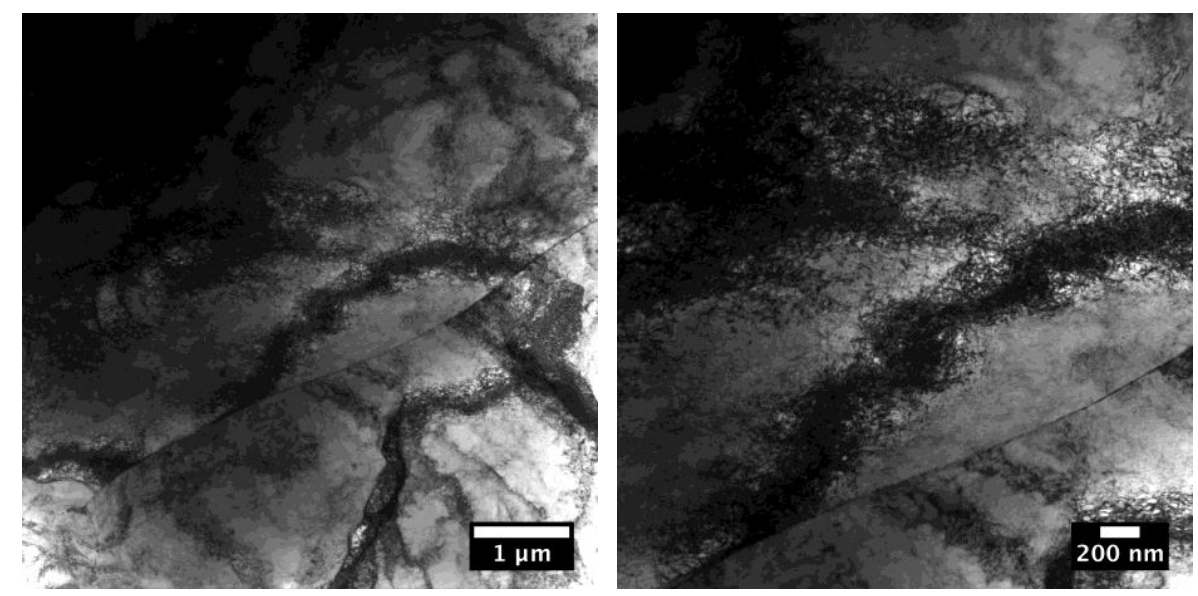

Figure 16. TEM micrographs showing the microstructure of the $1050^{\circ} \mathrm{C} / 1 \mathrm{~h}$ heat treated $\mathrm{AM} 316$ L SS after creep test at $550^{\circ} \mathrm{C} / 275 \mathrm{MPa}$. TEM specimen was taken from the gauge of specimen L205. 


\section{Location-Dependent Tensile Properties of AM 316L SS}

To evaluate the effect of part geometry on tensile and creep properties and to provide location-specific data to the TCR digital platform, 24 subsized SS-3 sheet-type specimens per rod were EDM-machined from rod L1-8 and L2-8, respectively of AM 316L SS provided by ORNL. Rod L1-8 was printed in laser 1 mode and rod L2-8 printed in lase 2 mode with the build ID of 20190315. The nominal diameter and length of the rods are 0.5 " $\times 4.2$ ". The nominal gauge dimensions of the SS- 3 specimen are 0.300 " $\times 0.060$ " $\times 0.035$ ". The specimens were oriented with the gauge in parallel with the build direction, and three rows of specimens were machined along the build direction with each row having eight specimens and four each symmetrically situated from the centerline of the cross section of the rod, as shown in Fig. 17. To track the location of each specimen, the length of the upper grip section of the specimen was increased by different amounts relative to the length of the lower grip section (instead of equal lengths as in a conventional specimen). Specifically, the upper grip is 0.09 " longer than the lower grip in the top row specimens, 0.06 " longer in the middle row specimens, and 0.03 " longer in the bottom row specimens. The location of a specimen within a rod is also tracked by the specimen ID. For example, the ID "1T1" has the first number "1" representing laser 1 mode, the second letter "T" representing the top section of the rod, and the third letter " 1 " showing the location of the specimen in the cross section of the rod (see the cross section view in Fig. 17).

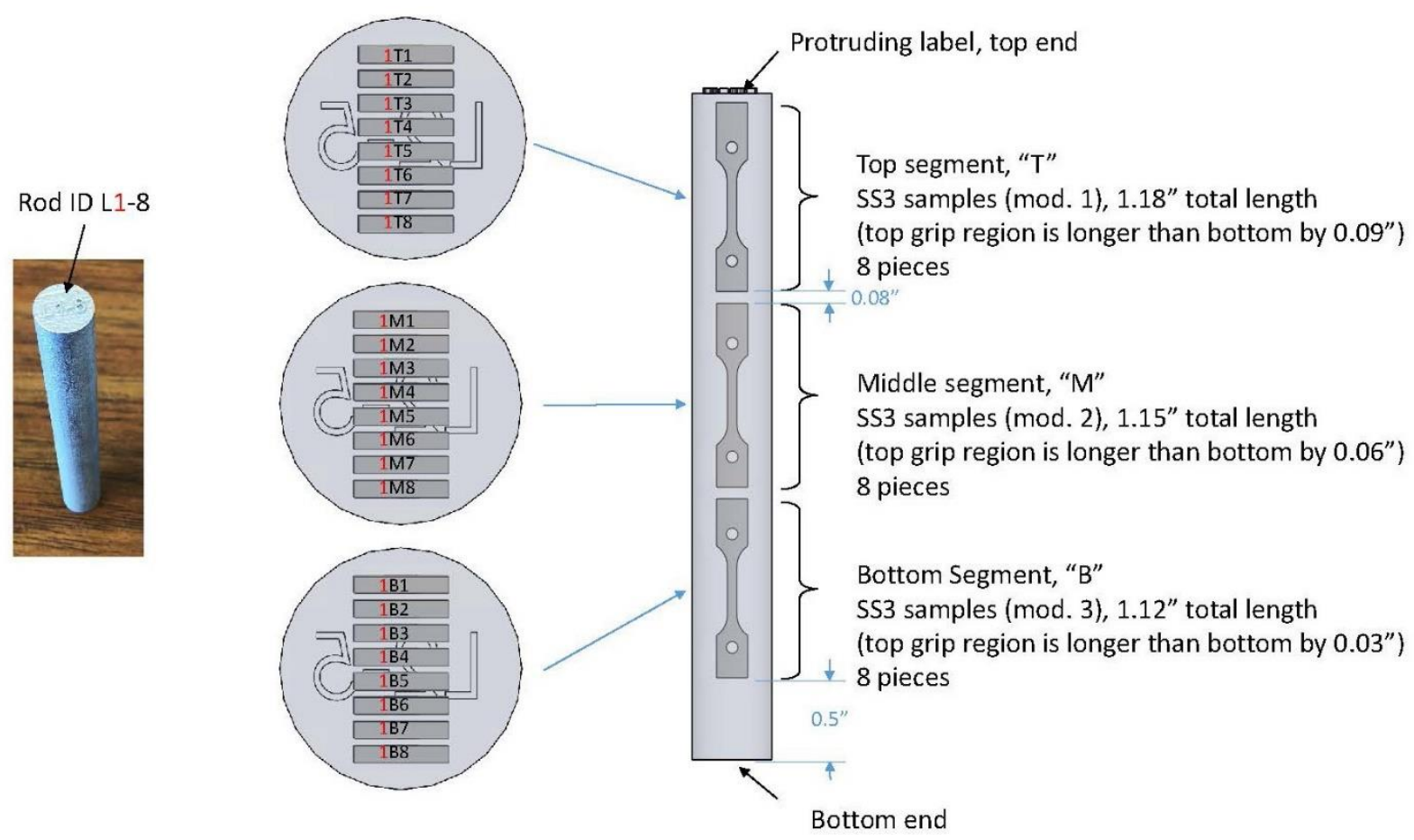



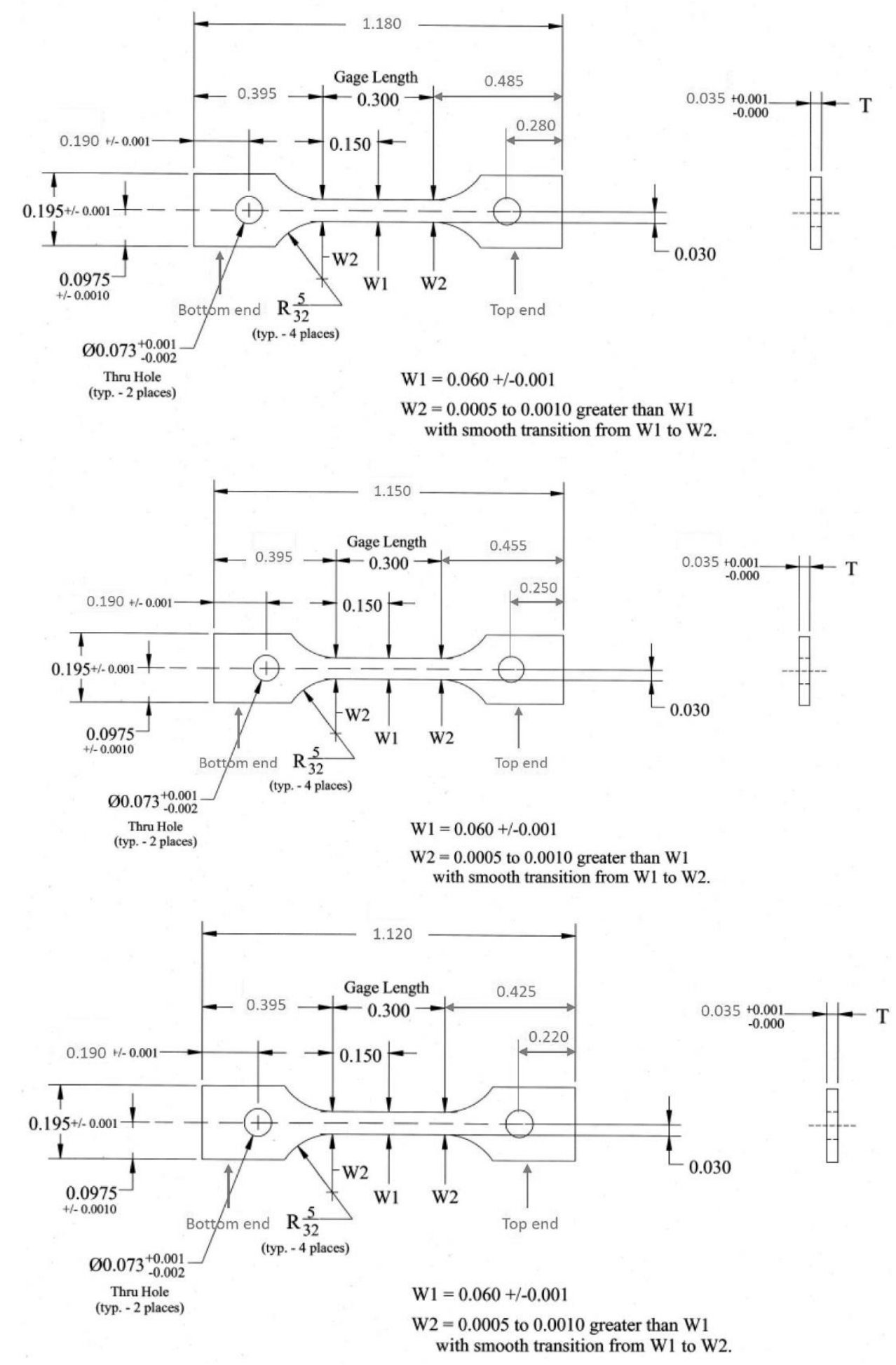

Figure 17. Specimen fabrication drawing showing the orientation and location of each specimen and schematic drawings of SS-3 sheet-type tensile specimens in the top, middle, and bottom sections of the printed rod (unit: in). 
Tensile tests were performed in an electromechanical testing system equipped with the Instron Bluehill software. Tests were conducted at $550^{\circ} \mathrm{C}$ at a nominal strain rate of $1 \times 10^{-3} / \mathrm{s}$ using a set of pin-loading grips. The applied load was recorded by a load cell; the specimen displacement was measured by the crosshead extension. The engineering tensile properties were determined from the analysis of the load and displacement data.

Figure 18 shows the engineering stress-strain curves of four specimens: two in the top section and the other two in the bottom section of rod L1-8. These four specimens showed remarkably similar tensile behavior with comparable yield stress (YS), working hardening rate, and ultimate tensile strength (UTS). Their tensile ductility, however, varied: specimen 1B4 has the lowest uniform elongation (UE) and total elongation (TE), and specimen 1T4 has the highest elongations, and both specimens are close to the centerline of the rod. Specimens 1B2 and 1T2, which are close to the periphery of the rod, have similar elongation values that are between the elongation values of specimens 1B4 and 1T4. There appears to be a location-dependence of tensile ductility, as illustrated in Fig. 19. Specimens in the middle section of rod L1-8 will be tested to provide further information. The tensile properties including yield stress, ultimate tensile strength, uniform and total elongations are summarized in Table 3.

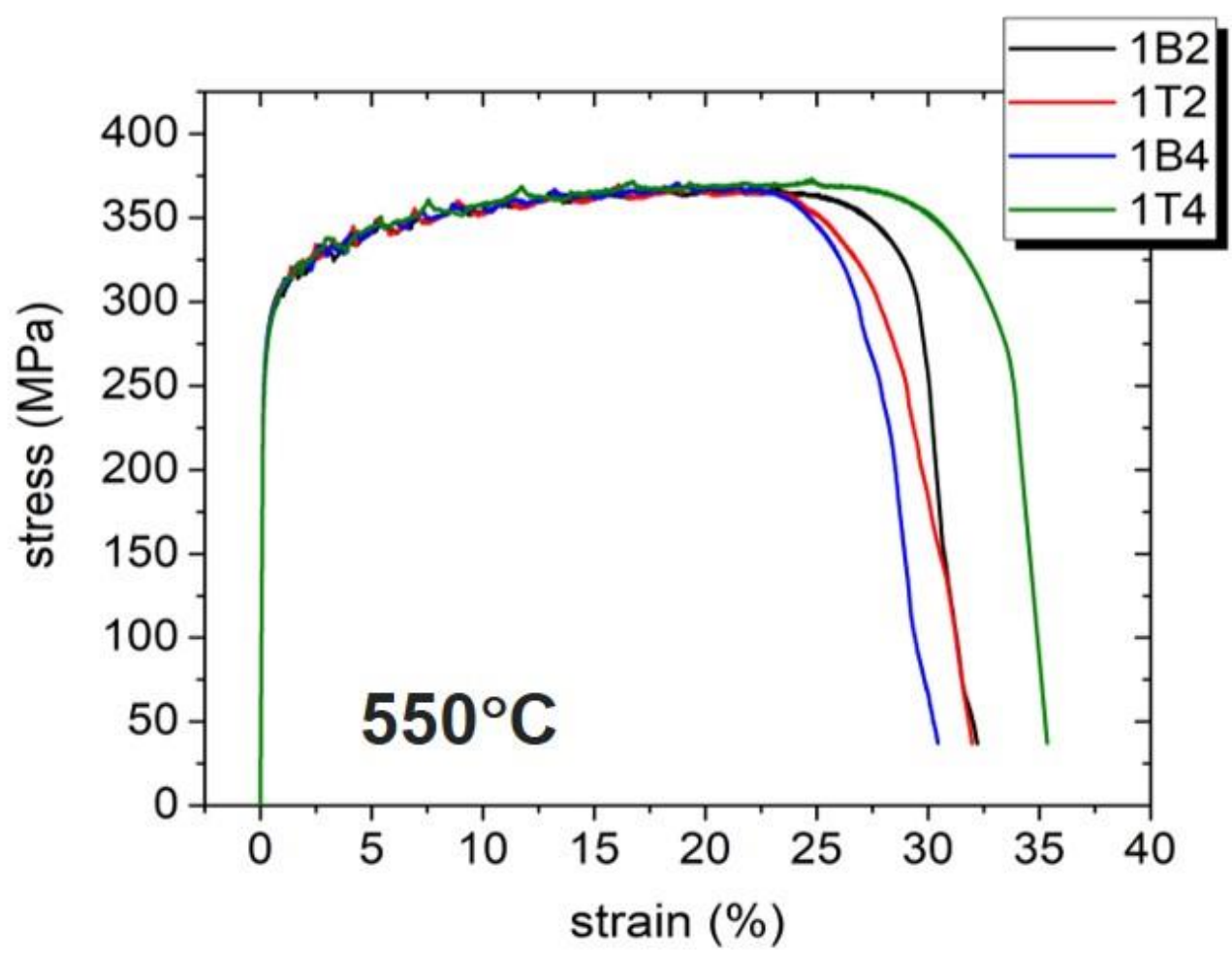

Figure 18. Engineering stress-strain curves at $550^{\circ} \mathrm{C}$ for specimens taken in the top and bottom sections of rod L1-8. 


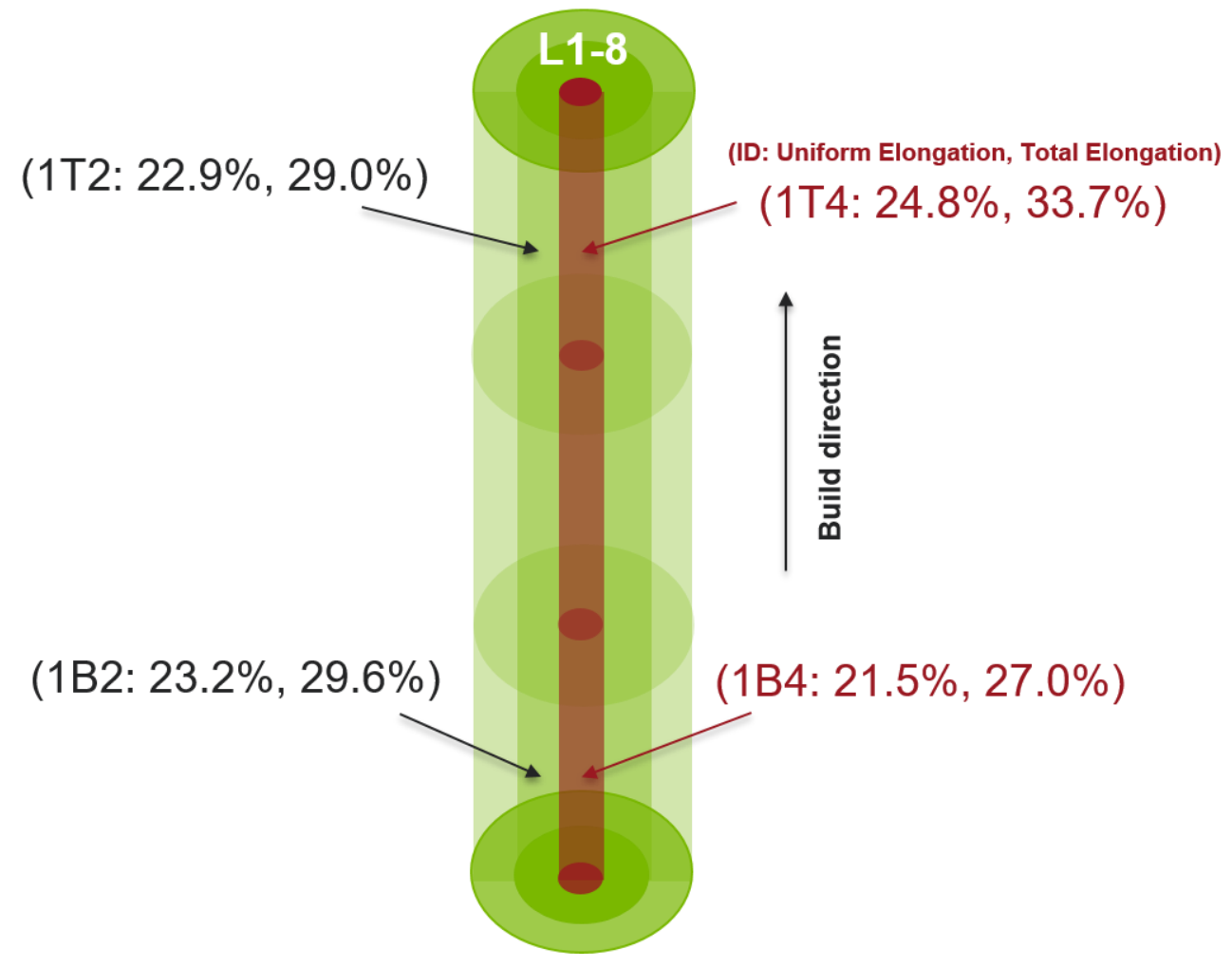

Figure 19. Illustration of location-dependent uniform and total elongation values in the printed rod L1-8. Tensile tests were conducted at $550^{\circ} \mathrm{C}$.

Table 3. Location-dependent tensile property data of AM 316 L SS.

\begin{tabular}{|c|c|c|c|c|c|c|c|c|}
\hline $\begin{array}{c}\text { Specimen } \\
\text { ID }\end{array}$ & $\begin{array}{c}\text { Rod } \\
\text { ID }\end{array}$ & $\begin{array}{c}\text { Specimen } \\
\text { Type }\end{array}$ & $\begin{array}{c}\text { Test } \\
\mathrm{T} \\
\left({ }^{\circ} \mathrm{C}\right)\end{array}$ & $\begin{array}{c}\text { Strain } \\
\text { rate } \\
(1 / \mathrm{s})\end{array}$ & $\begin{array}{c}\text { YS } \\
(\mathrm{MPa})\end{array}$ & $\begin{array}{c}\text { UTS } \\
(\mathrm{MPa})\end{array}$ & $\begin{array}{c}\text { UE } \\
(\%)\end{array}$ & $\begin{array}{c}\text { TE } \\
(\%)\end{array}$ \\
\hline 1T2 & L1-8 & SS-3 & 550 & 0.001 & 281 & 370 & 22.9 & 29.0 \\
\hline 1T4 & L1-8 & SS-3 & 550 & 0.001 & 277 & 373 & 24.8 & 33.7 \\
\hline 1B2 & L1-8 & SS-3 & 550 & 0.001 & 277 & 368 & 23.2 & 29.6 \\
\hline 1B4 & L1-8 & SS-3 & 550 & 0.001 & 281 & 371 & 21.5 & 27.0 \\
\hline
\end{tabular}

\section{FUTURE WORK}

Work on location-dependent tensile property will continue. Tensile tests at different temperatures and at lower strain rates are planned. Location-specific creep property data will also be produced using subsized SS-3 specimens. Four ASTM standard size round bar creep specimens in laser mode 1 and laser mode 2, respectively and three ASTM standard size round bar creep specimens in laser mode 1 and laser mode 2, respectively were fabricated from printed rods and 
are ready to be tested. Creep and low-cycle fatigue tests at 550 and $600^{\circ} \mathrm{C}$ have been planned for these specimens.

We have recently received materials from ORNL including a new build of AM 316L SS, wrought 316L SS, and AM IN718. Subsized specimens will be fabricated from the materials and will be used for the evaluation of tensile, creep and fatigue properties.

\section{ACKNOWLEDGEMENT}

Work was supported by the Transformational Challenge Reactor Program funded by the U.S. Department of Energy, Office of Nuclear Energy under Contract DE-AC02-06CH11357. Materials were provided by Oak Ridge National Laboratory. Use of the Center for Nanoscale Materials, an Office of Science user facility, was supported by the U.S. Department of Energy, Office of Science, Office of Basic Energy Sciences, under Contract No. DE-AC02-06CH11357. We would like to thank Ed Listwan, Joe Listwan and David Rink for assistance of tensile and creep tests.

\section{REFERENCES}

1. Z. Sun, X. Tan, S.B. Tor, C. K. Chua, "Simultaneously enhanced strength and ductility for 3Dprinted stainless steel 316L by selective laser melting," NPG Asia Materials 10 (2018) 127.

2. Y.M. Wang, T. Voisin, J.T. McKeown, J. Ye, N.P. Calta, Z. Li, Z.Zeng, et al., "Additively manufactured hierarchical stainless steels with high strength and ductility", Nature Materials 17 (2018) 63.

3. G.T. Gray III, V. Livescu, P.A. Rigg, C.P. Trujillo, C.M. Cady, S.R. Chen, J.S. Carpenter, T.J. Lienert, S.J. Fensin, "Structure/property (constitutive and spallation response) of additively manufactured 316L stainless steel", Acta Materialia 138 (2017) 140.

4. Oak Ridge National Laboratory. "Transformational Challenge Reactor," Oak Ridge National Laboratory. https://tcr.ornl.gov/.

5. J. Simpson, J. Haley, C. Cramer, O. Shafer, A. Elliott, W. Peter, L. Lover, R. Dehoff, "Considerations for application of additive manufacturing to nuclear reactor core components," ORNL/TM-2019-1190, Oak Ridge National Laboratory (2019).

6. K.G. Field, J. Simpson, M.N. Gussev, H. Wang, M. Li, X. Chen, T. Koyanagi, K. Kane, A.M. Rossy, M. Balooch, K.A. Terrni, "Handbook of advanced manufactured material properties from TCR structure builds at ORNL - FY19," ORNL/TM-2019/1328 (2019).

7. C. R. Brinkman, "Elevated-temperature mechanical properties of an advanced Type 316 stainless steel," ORNL/CP-101053.

8. S. Li, J. Ju, W. Chen, J. Yu, M. Li, Y. Wang, "Evolution of cellular dislocation structures and defects in additively manufactured austenitic stainless steel under ion irradiation," Script Mater. 178 (2020) 245. 


\section{Argonne}

Nuclear Science and Engineering Division

Argonne National Laboratory

9700 South Cass Avenue, Bldg. 401

Argonne, IL 60439

www.anl.gov 